\title{
EC 官僚制と加盟国の関係
}

一人事政策をめぐる諸問題——

\section{福 田耕治}

\section{は じめに}

E C 官僚制とは何か。それは「E C 職員規程」の下で共同体と雇用関係に ある者が人事配置された事務局である，と定義される。では，この国際事務

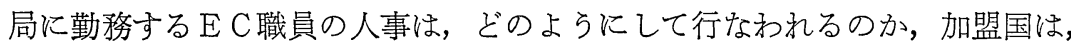
これに対して何らかの影響力を行使できるのであろらか。この問題について E C は，その統合過程を通じてひとつの回答を与えつつある。同時にこの問 題は「民主主義の国際化」，「行政の国際化」といら課題とも密接にかかわ っている。すなわち国際官僚制に対する民主的統制はいかにあるべきで，E Cレベルの「国際行政」が，加盟国の国内行政をいかなる形で取り込んでい るのか，といった国際行政研究の非常に興味深い素材を提供している。 かつてド・ゴールは，「無国籍で無責任，かつ吞気な」ブリュッセルのテ クノクラートには「諸国民の意見や運命を左右する権威も，資格もない」と 述べ，E C官僚制を痛烈に批判した。しかし四半世紀を経た今，欧州統合の 隠れた担い手として，E C官僚制が果してきた役割は決して軽視できない。 なぜなら E C の政策決定ととの実施のために， E C 委員会の官僚制は，さま ざまなレベルで「E C 行政と加盟国行政の関係」を調整し，加盟国側の協力 
や国内政策の調整を促してきたからである。

そこで本稿は，人事政策をめぐる問題に焦点をあて，まず第 1 に， E C の 行政官僚制，公務員制度が，加盟国との関係でいかなる経緯を経て形成され たのか，第 2 に，加盟国は，対 $\mathrm{E} \mathrm{C}$ 人事政策や国内政策の総合調整のために， ぞのよらな行政対応をしたのか，これらを踏まえて，第3に，EC委員会の 国際官僚制に䑙惊高級官僚（A類）の人事決定は，いかにして行なわれ， 加盟国はこれにどの程度関与できるのか，また E C 職員の人事政策にはどの ような問題点があるのかを検討してみたい。

1) STATUT, Règlements et réglementations applicables aux fonctionnaires et autres agents des Communautés européennes., Mai 1978.

2) Wessels, W., "Community Bureaucracy in a Changing Environment: Criticism, Trends, Questions", Jamar, J., Wessels, W. eds., Community Bureaucracy at the Crossroads, L'administration communautaire à l'heure du choix, Collège d'Europe, Bruges, 1985，p.12. これは法的な意味での定義である。1983年現在，E C 委員会の事務局には， 13,746名の職員が勤務する。な特，欧州議会には 3, 166 名，閣僚理事会には 1,810 名， E $\mathrm{C}$ 裁判所には 507 名, E C 会計検查院には 312 名, 経済・社会評議会には 418 名の職員が 在職する事務局がある。本稿では E C 職員の 7 割以上が在職する E C の行政府, E C 委員 会の事務局を分析の対象とする。第1章の注 14)参照。

3）金丸輝男「歩き出したE C 旅券同盟 Passport Union」『デモクラシーの思想と現実』法 律文化社，1985年，262-3 頁参照。

4) Wessels, W., op. cit., p. 9.

5） 1960年10月，ド・ゴールがアンシイ遊説中に行なった演説。嬉野満州雄編著『ドゴール の言葉—々の演説・声明・著書・談話から』日本国際問題研究所, 1964年, 83頁。

\section{E C 官僚制の形成と加盟国}

\section{$1 \quad$ E C 委員会官僚制と公務員制度の形成}

国際組織の運営には，執行機関の強力なリーダーシップ，複雑かつ専門的 な行政事務を遂行できる事務局の存在が不可欠である。なぜならそれは国際 的な共通の公共政策の形成・決定作成の準備に関与し，執行にも重要な役割 
E C 官僚制と加盟国の関係（福田）

を演じるからである。E Cにおいては，EＣ委員会が共同体の執行府として その役割を担い，共通政策のための各種法案や仮予算案を作成し，主たる決 定機関である閣僚理事会へ提案する。また $\mathrm{E} \mathrm{C}$ 予算を執行し，各種共同体基

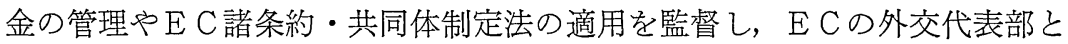
して国際協定の締結交渉にも山たる。

このような政治的機能と行政的機能を合わせもつ E C 委員会は，具体的に 2) は国家でいえば内閣に例えられる17名の委員 (1986年現在) からなる意思決定 機関，政治的機関としての委員会と，これを支光る1万数千名の国際公務員 からなる事務局によって構成される。一般に，「EC委員会」といら機関に ついて言及される場合，この両者が区別されることはほとんどないが，その 3) 役割は全く異なっている。各委員は国家に和ける大臣の役割を演じ，各自の 管轄事項に対応する行政事務局——国家でいえば省にあたる「総局」(Directorates General) やその他の行政単位——を指揮・監督し，行政事務を分担管 理する。とはい光，E C 諸条約に拈いては委員会についての規定はあるもの の，その事務局の内部行政については何ら言及していない。ただ，一般規定 において機関運営を確保するため, 委員会の提案に基づき「職員規程和よび その他の被雇用者に適用される雇用条件」を定めるよう閣僚理事会に 要請 （EＥＣ条約第 212 条，EAEＣ条約第186条）しているだけであった。

そこで閣僚理事会は，1958年11月 E E C ， E A E C 委員会と協力して職員 4) 規程の作成に着手した。同年12月に理事会から同草案の起草を依頼された常 駐代表委員会 (COREPER) は，各加盟国の行政官庁の專門家，E E C , E A E C 委員会の委員で構成される作業部会にとの仕事を委嘱した。1959年11月 8 日，理事会は 2 つの新しい共同体職員の給与体系に関する条項を採択した がこれはEＣＳＣのそれよりも平均 $6 \%$ 低いものであった。

1960年 9 月，1961年 2 月には職員規程案，共同体税規則案が理事会の第 1 7)

読会を通過し，条約に従って欧州議会に諮問された。欧州議会は，1961年10 月19日，次のような見解を示した。それは三共同体の執行機関を将来併合す 
る観点から, 新しく制定される両共同体の職員規程を, 既存の E C S C の勤 務関係法規にできる限り近づけるべきであるとする見解である。

この要請を配慮したE E C ，EＡＥＣ理事会は，EＣＳＣ理事会とも協力 して三共同体汇統一的な職員規程を作るよう試みた。しかし，給与水準の差 なぞについてはEＣＳＣ当局との調整がつかなかったため，1961年12月18日， 理事会はとりあ兄ず E E C ， E A E C 亿のみ適用される職員規程を採択し， 翌62年 1 月 1 日から施行しだ。とはい方この職員規程は, 職員の一般的義務, 勤務条件等，原則的にはＥＣＳＣの勤務関倸法規々ほぼ同様のものになった。 しかし，職階制，給与水準，年金制度なぞには若干の相違点がある。るた， E C S C 勤務関係法規にはみられない特徴として，新しい職員規程では，先 の職員が恒久職に就く「官吏」(fonctionnaires，officials）と臨時職の「その他 の被雇用者」(autres agents，other servants）に区分されたことを挙げられる。 もっとも，「官吏」と「非官吏」を区別する考兄方はフランスやドイツをは じめ大陸諸国の公務員制度に和いてもむしろ一般的にみられれ，これは加盟国 の公務員制度を範として作成されたことによるものであるともいわれている。

では，実際に恒久職と臨時職の割合は，いかなるものであららか。1983年 度予算では，共同体職員全体 $(19,959$ 名）の約 $95 \%$ 以上が恒久職住就き， E C 委員会事務局職員化限ってみても，その $94 \%$ 恒久職，すなかち常勤職員 となっている。その理由は，加盟国が「共同体の業務遂行は，原則として恒 久的汇設定された勤務関係のもとになされるべきである」と決定していたこ とによる。これは他の国際組織には例のない特色であるとい光る。なぜなら， 国際連合職員は臨時職員が約 $45 \%$ を占め (1978年現在)，二ネスコ職員は約 67. $2 \%$ が臨時職員（1975年現在）で㐫り，O E C D 職員の場合には全員が臨時 職員となっているからである。つまり E C の国際公務員制においては，他の 国際組織の職員とは異なり，一般の国家公務員之同様に職員のキャリア展開 を認める組織形態をとっているといら特徴を指摘できる。

1956年 4 月 8 日の「併合条約」(1967年 7 月 1 日発效) 第 9 条の下で， $\mathrm{E} \mathrm{C}$ 
S C の最高機関， E E C ，E A E C の委員会が単一の E C 委員会に併合され た。これに伴い，同条約第 24 条及び附属の「E C の特権と免除に関する議定 書」第13条の下で，E C S C 職員の勤務関係法規もE E C , E A E C の職員 規程に準ずるよら改正され, 単一の職員規程が作成されることになった。こ うして1968年 2 月29日の閣僚理事会規則第259号 (EEC, EAEC, ECSC, No. 18)

259/68）により，現行の E C 職員規程（E C の官吏規程・その他の被雇用者に適 19)

用される雇用条件)が制定されたのである。以後，1973年，1981年，1986年の 共同体の拡大に際して若干の部分的修正が加えられて現在に至っている。

\section{E C 委員会官僚制の構造と加盟国の立場}

E C 委員会事務局の内部行政組織は，我が国の国家行政組織と同様，専門 分野別にいわゆる「綎割」の業務分担がなされている。1985年現在，全体で 29の行政単位により構成されているが，その主要なものは各政策領域に対応 20) した20の総局である。各総局間の総合調整に重要な役割を演じるのは，事務 総局 (Secretariat General) と法務部 (Legal Service) であるが，財政や人事 管理を通じての調整機能は，予算総局 (DG-XIX)，人事・行政総局 (DG-IX) に委ねられていることを見逃してはならない。各総局は, さらに複数の局, 課などに分かれるピラミッド型の階層構造を持ち，一つの指揮系統中には原 則として異なる国籍の職員が配置されるよう配慮されている。なぜなら，一 つの政策領域に特定国出身の職員が集中した場合，共同体全体の利益よりも 母国の利益を優先する染意的な政策立案が行なわれる可能性があるからであ る。それゆ光特に行政裁量が認められる分野に和いて超国家的観点に立った 判断ができるようにするため，原則としてA類上層（A1〜A3）等級職につ いては，総局長がイタリア人であれば補佐はフランス人，その部下はオラン ダ人という具合に「多国籍人事」(multinational staffing) が行なわれることに 22) なった。しかしこれはあくまで「原則」に過ぎず，職員の国籍と能力との関 係から後述するような複雑な問題が生じることも少なくない。 
以上のような構造をもつ E C 委員会の官僚制に対し, 加盟国はいかなる立 場をとってきたのだろらか。

各加盟国に拉いては，国家から完全に独立した超国家的官僚制は受け入れ 難いばかりではなく，共同体の運営を実効あるるのにする観点からる問題が 少なくない，といら認識が次第に強まっていった。例兄ばフランスは，当初 から共同体が独自の官僚制，超国家的公務員をるつことにかなりの難色を示 し，各国の国家公務員を一定期間だけ $\mathrm{E} \mathrm{C}$ の事務局へ出向させる方式を強く 主張した。

しかしこの「派遣制度」の是非についてEE C 委員会で審議した結果，全

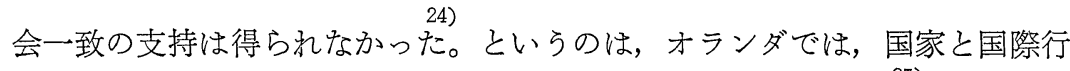
政機関に和污重の官吏関倸の発生を制限しているからである。るた，短 期間の E C への出向では， ECの行政事務への習熟や継続性飞問題が生じる ばかりか，これらの官嘹にE C 亿対する忠誠心を芽ば兄させることもできな いであうう。このような理由から，国家公務員と国際公務員を兼任させる方 式は拒否され，ECは原則として独自の「欧州官僚」(Eurocrats)からなる超 国家的性格をるつ官僚制を擁することになった。

しかし，このような加盟国の立場を踏ま兄た討議の結果，ECの官嘹制は 加盟国政府・官僚制の影響力を完全に排除するのではなく，むしろこれを Cの政策形成過程に組及込んでいく途を選えだ。すなわちE C 委員会は,

「運営委員会」(Management Committee) 等の加盟国の国家公務員・専門家で 構成される下部委員会を通じて，自らの提案を行なら前炕各加盟国の意見を 可能な限り共通政策に反映させるようにしたので㐫る。同様の観点から， E $\mathrm{C}$ の政策形成や執行に関与する $\mathrm{E} C$ 官僚制の行政幹部 $\mathrm{A}$ 類職員の人事につい ても妥協的な解決が図られた。つまりA類職員の採用方法を，(1)各加盟国政 府による推薦に基づく，事実上の政治的任命を認める $\mathrm{A}$ 類上層 (A1 3) 官 職と, (2)競争試験による能力の実証に基づく, いわゆる「メリット・システ ム」による任命を行なうA 4〜8官職に分け，二つの入口選別の方法を制度 
化したのである。A類上層官職への職員の任命は，共同体としても候補者に 関する十分な情報を得るため，各加盟国政府にまず相談せざるを得ない。 $\mathrm{E}$ C 委員会は各国政府の推薦や助言を尊重し，さらに当該部局における職員の 国籍均衡を考慮して政治的任命を行なう。とはいえ，どの国籍の候補者をど の官職に任命するかは，山くまで E C 委員会の決定権限内にある。だが各国 レベルでの候補者の選任については，各加盟国の裁量に委㸚られる。るっと も上層官職への政治的任命を認めること自体は，フランスをはじめ他の加盟 国でも一般的に行なわれている。乙かし，これは E C 職員規程の制定過程で， フランス公務員法独自の観念が色濃く反映された結果である，とD・クーム ズ (David Coombes) 教授は指摘している。

さらに加盟国との連絡, 連繫を図るものとしては，EC委員会に拈ける委 員官房 (cabinet) 組織の存在がある。前途のように，行政事務を分担管理す る責任があるのは個々の委員であった。一人の委員が複数の総局やその他行 政単位の活動を十分把握することは，時間的にも能力的にも不可能に近い。 そこで各委員の職務を補佐するために設けられたのが，各委員の「私的な事 務局」(private office) としての委員官房である。これはフランスの大臣官房 (cabinet ministriel)を範として抒り，通常当該委員と同国籍の 5 〜 数名の 31) 職員で構成される。その職員の任命権は個々の委員にあり，その任期も当該 委員の任期と同一である。各委員官房は, 委員とは別人である官房長 (chef de cabinet)によって統轄され，一般にフランスの官房，ドイッの官房，…... と呼ばれる。このことからもわかるように, 官房職員は E C 職員よりも明ら かに国家代表的性格が強いといえる。17名の E C 委員会においては，各委員 が各自の官房から得られた情報をもとに問題を討議し，決定を下すことが可 能となる。しかし，各委員が各自の官房に依拠せざるを得ないために，逆に $\mathrm{E} C$ 職員の人事決定に和いて後に述べるよらな多くの複雑な問題を惹起する ことになる。

1） E C の国際協定，加入条約締結交渉過程に和ける E C 委員会の役割化関する䛨細は，拙 
稿「E Cに和ける民主主義とヨーロッパ議会一国際協定締結に対する議会統制を事例とし て」『デモクラシーの思想と現実』法律文化社, 1985年を参照されたい。

2) Instruments Concerning the Accession of the Kingdom of Spain and the Portuguese Republic to the European Communities, Vol.1, Article 15.

3) Wessels, W., op. cit., p. 9.

4) EEC Commission, 5th GEN. REP. EEC, 1962, point. 298.

5) Ibid.

6) Rogalla, Dleter, Fonction publique européenne, Fernand Nathan, Paris, Editions Labor, Bruxelles, 1982, pp. 16-7.

ヘルバート・ブルンス「ヨーロッパ共同体の官吏規則」(Das Beamtenstatut der Europäischen Gemeinschaften, 1962) 人事院法制課訳「ヨーロッパ共同体の官吏制度」調査 研究参考資料第102号, 1965年, 4-5 頁。

7) 同上。

8）同上, 9 頁。

9) EEC Commission, 5 th GEN. REP. EEC, op. cit., point. 298.

10) Ibid.

11) Ibid.

12) Rogalla, Dleter, op. cit., p.16.

13）例えば，室井力『特別権力関係論—ドイッ官吏法理論をふまえて』勁草書房，1979年， 213頁。森園幸男「欧米に护公公務員の昇進制」『季刊・人事行政』1979，No.12. を参 照。

14) Strasser, Daniel, Les Finances de L'Europe, Cinquième édition, Labor Nathan, 1984，p.504. から筆者が\%計算をした。

15）ヘルバート前揭論文，12頁。

16) Siedentopf, Heinrich, "The Principles and Practices of Recruiting International Civil Servants", XIX th International Congress of Administrative Sciences, KLUWER, 1983, pp. 105-6.

17) Cartou, Louis, Communautés européennes, Septième édition, Précis Dalloz, pp.147-8.

18) Council Regulation (EEC, EAEC, ECSC) No, 259/68, OJ No. L 56, 4. 3.1968 (1968 年 3 月 5 日施行). $\mathrm{EC}$ 職員の所得税も同規則で定められた ( $E$ C 財源に入る)。

19) STATUT, Règlements et réglementations applicables aux fonctionnaires et autres agents des Communautés européennes.

20) Directory of the Commission of the European Communities, Office for Official Publications of the EC, June 1985, pp.3-4.

21) Strasser, Daniel, The Finances of Europe, Office for Official Publications of the EC, 
1981, pp. 314-5.

22）ウェルナー・J・フェルト「欧州共同体の人事管理」(Werner J. Field, “Personnel Administration of the European Communities”, Public Personnel Review, 1964)人 事院法制課訳，調查研究参考資料第91号「E E C の官吏制度」1961年，2－3 頁。

23）拙稿「E C コミッションに扮ける人事行政——幹部（A類）官吏採用・昇進制度の現状 々問題点」『同志社法学』第168号，1981年，73頁。Coombes, David, Politics and Bureaucracy in the European Community, London, Allen \& Unwin, 1970, p. 121.

24) Ibid.

25）ヘルバート前掲論文，56頁。Siedentopf，H., op. cit., p. 109.

26）運営委員会手続は，多くの農産物市場組織の段階的形成との関連で1962年 4 月 4 日の規 則 (regulation)により導入された。現在では農業以外の多くの分野でも活用されるよう になっている。運営委員会は，E C 委員会の代表が議長となって加盟国の代表により構成 される。但し，議長には投票権はなく，各加盟国代表が理事会の特定多数決手続（E E C 条約第148条) 飞従って決定する。Bertram, Christoph, “Decision-Making in the EEC; The Management Committee Procedure”, C. M.L. Rev., Vol. 5, (1967-68), p.246., Schindler, Peter, "The Problems of Decision-Making by Way of the Management Committee Procedure in the European Community", C. M. L. Rev., Vol. 8 (1971), pp. 184-205.

27）前揭拙稿，82-3 頁。 $\mathrm{E} \mathrm{C}$ 職員規程第29条第 2 項。

28） E C 職員規程第29条，附属書吕。

29) Coombes, D., op. cit., p. 135.

30) Michelmann, J.H., Organisational Effectiveness in a Multinational Bureaucracy, Saxon House, 1978, p. 18.

31) Sydow, Helmut Schmitt von, Organe der erweiterten Europäischen Gemeinschaften-Die Kommission, Nomos Verlagsgesellschaft Baden-Baden, 1980, S.93-6.

Scheuer, Hans \& Weinstock, Ulrich, Administrative Strukturen der Europäischen Gemeinschaft, Europa Union Verlag GmbH, 1977, S.90-1. 委員官房の役割について 詳細は，前揭拙稿77頁を参照されたい。

32) Michelmann, J.H., op. cit., p.18.

33）前揭拙稿, 76頁。 Michelmann, J.H., "Multinational Staffing and Organizational Functioning in the Commission of the European Communities", International Organization, Vol.32, No.2, Spring 1978, p. 482. 


\section{II 加盟国官僚制の対応と E C 職員の国籍別在職状況}

\section{1 各加盟国官僚制の対応}

各加盟国は，一方では共同体諸機関，とりわけ E C 委員会総局の上層主要 官職へ自国民を送り込み，自国の政策を共同体の政策形成に反映させたいと 考える。そのためには，この上層官職への自国民候補者の人事選考を行なら ために省庁間の調整が不可欠となる。他方では，各加盟国が共同体の政策や 手続を受け入れるため，国内の省庁間で個々の政策や手続を総合的に調整す る必要が生じる。すなわち E C の特定の政策 (例觉ば地域政策)を実施するに しても，加盟国では複数の省庁の所管となっていることが多いため，省庁間 の意見調整が必要である。そこで各加盟国は，新たな行政規則の制定や総合 調整機能をもつ新しい機関を設置するなど，行政制度の改革を余儀なくされ た。それはいかなるものであったのだろらか。加盟国に和ける行政官僚機構 の制度的対応を人事政策との関連でみてみよう。

まず，高度に中央集権的な官僚制を持つことで有名なフランスでは，首相 に対して直接責任を負ら「省際委員会事務局」(Secrétariat général du Comité interministériel: SGCI) が E C 問題を扱らために設置されている。この機関の 前身は，マーシャル・プランによる援助を受け入れるために1948年 6 月 25 日 の政令 (décret) により設置された欧州経済協力問題省際委員会の事務局で あり，1952年 9 月 3 日，1958年 4 月 3 日の政令により，パリ条約，ローマ条 約の要求に適合させるべく改組されて現在に至っている。この機関には約 100 名の公務員が配属され，大統領に対しても経済上の助言を与兄，関係省 庁間の意見調整を図る機能がある。フランスでは共同体政策をめぐる問題は， 外交政策の一部であるという見解学とり，省際委員会事務局は，外相，外務 省とも緊密な連絡をとる。同事務局は，外務省経済金融局欧州課から情報を 得て， E C 委員会による E C 制定法の草案準備段階でフランスの政策と適合 
E C 官僚制と加盟国の関係（福田）

6)

させるよら影響力を行使する努力をする。

1981年までは，首相又は彼が不在の場合，蔵相がこの省際委員会事務局を

監督してきた。その後，外相に欧州問題に関する権限が与えられたが，1983 年12月に欧州問題相が任命されて以降は同相にとの権限が移された。省際委 員会事務局は，EＣの決定がフランスの政策に及ぼす影響を検討し，ブリュ ッセルのフランス常駐代表部や作業部会に派遣されている国家公務員に対し て訓令する。また外務省の人事・総務局(Personnel et Administration Général) の国際公務員課は，E C 委員会の各総局の主要官職へのフランス人派遣問題 10) を扱ら。対 E C 人事問題をはじめ，全ての省朾間調整は，公式の手続ばかり でなく外務省職員と常駐代表部上層職員との間での非公式かつ個人的な関係 による協議を通じて行なわれる場合も少なくない。

一方，西ドイッでは，当初共同体問題は経済政策の一部とみなされ，連邦 経済省 (Bundesministerium für Wirtschaft) がリーダーシップをとることを主 張した。1959年，同省に欧州局が設置されるに伴いこれが確定し，連邦外務 省と共にその責任を分担してきた。しかし西ドイッの対欧州政策が，さらに E C の諸政策と「歯車のかみ合う」ものとする必要から，1973年 1 月17日の 決定により，「内閣欧州政策委員会」(Kabinettausschuß für Europapolitik) を 設置し，連邦首相官房 (Bundes Kanzleramts) が調整に大きな役割を担らこと になった。また対 E C 人事政策上の対応としては，1973年 9 月25日，多国籍 組織または超国家的組織への連邦公務員の派遣のための行政規則を採択した。 その骨子は，次のようなものであった。

連邦公務員は，との給与の停止と共に公職を離れることが認められる。但 し，派遣の期間は無期限であり，国際組織に和ける勤続年数は将来帰国し， 連邦公務員に復職しても昇任のための期間には加算されない。復職する場合 は，出国前の元の官職か，それと同等級の欠員官職とする，というものであ った。これはオランダのよらに国際公務員になるために，国家公務員を退職 しなければならないのと比較すれば，帰国後の復職を保証する点で連邦公務 
員にとって望ましい規則であるといえる。とはいえ， E C 勤務で得た知識や 技能は， E C 関係省の特定官職以外では役立てられず，昇任にとっては考慮 されないばかりか，本国にいた者よりも昇任の時期が遅れる点で不利になる。 では，なぜこのような制度をとっているのか。それは E Cへの出向者の連邦 公務員への復職が，本国にいる公務員のキャリア見通し (Career prospects) と衝突するためこのような措置をとらざるを得ないと考兄られる。シーデン トップ (Heinrich Siedentopf) 教授によれば，これは国際組織へ連邦公務員を 派遣する場合に，最終的な人事決定権をもった中央レベルの調整機関が西ド イッに和いては存在していないといら欠陥から生じる問題である，と指摘し 19) ている。

イタリアに执いては，当初，欧州政策，共同体問題は，外交政策の一部と みなされていた。そんのため各省庁間の総合調整問題に取り組むのはやや遅れ たが，1967年12月27日に「経済計画省際委員会」(Comitato Interministeriale per la Programmazione Economica)を法律第48号により設置した。この機関は, 首相又はその代理として予算・経済計画活動相が議長となり，13名のメンバ 一で構成された。その主たる目的は, 国内の経済政策をパリ条約, ローマ条 約の要請に適合させるために，省庁間の調整を行ならことであった。しかし 政治的レベルでの調整は功を奉することはできず，その後，事務レベルでの 調整に力点が移された。すなわち「総局長会議」(Riunione dei Directtori Generali)が，実質的な調整機能を果すことになった。これは外務省経済問題 総局長が議長となり, 関係各省の総局長で構成される。とはい各各省の権限 にかかわる重要問題が交渉される場合には, 既得権死守の傾向から同会議が 単なる情報交換の場に值することも少なくないといわれる。いずれにせよ， 現在では外相扔よび外務省経済問題総局第一部 $\mathrm{E} \mathrm{C}$ 課が共同体問題に関する 主要な任務を担当している。また対 $\mathrm{E} C$ 人事政策は，海外職員組織網を管理 する外務省人事・行政総局の第 3 局に委水られている。

ベネルックス三国でも，共同体問題は外務省の所管とされ，外務大臣に主 
E C 官僚制と加盟国の関係（福田）

29)

たる任務の責任が負わされている。

しかしながら，以上の原加盟国，大陸諸国とはかなり異なる法体系，統治 機構, 行政制度をもつイギリスでは，加盟に伴ら行政機関相互の調整は重大 問題といわざるを得なかった。とはいえ，1961年に加盟申請して以来，加盟 に伴ら行政対応は不可避であるとの認識から，長期にわたる検討が続けられ てきた。1971年10月28日にイギリス議会下院に和いて共同体加盟の原則が承 認されるや行政機構の再編が着手された。

加盟当時イギリス外務連邦省（以下，「外務省」とする）には，対欧州問題と 加盟交渉を担当してきた統合欧州局が置かれていた。これはマーシャル・プ ランの下での欧州復興課をその前身とする機関であったが，1973年以降は域 外関係と域内関係をそれぞれ扱ら2つの統合欧州局に分けられた。さらに 1980年からはE C 域外局, E C 域内局之改称され現在に至っている。共同体 への加盟が事実上確定した1971年末，この外務省の機関とならんで内閣官房 のなかに欧州班 (European Unit) が設置された。その目的は，加盟に伴ら $\mathrm{E}$ C対策としての国内各省庁間の総合調整にあった。つまりこれは19世紀中葉 以来イギリスに伝統的な大蔵省統制 (Treasury Control) から，大蔵省と1968 年11月に新設された行政管理省 (Civil Service Department) による統制機能 の分担を経て，各省よりも中立的な位置にある内閣官房へと行政の統制，総 合調整機能が移ったことを意味する。

さらに国内問題の「欧州化」に積極的な姿勢をとったエドワード・ヒース 首相は，内閣官房の次官補 (Under Sectetary) を議長として E C関係省参事 官 (Assistant Secretary) による欧州問題事務委員会（EQO）を組織した。 同委員会は，E C 閣僚理事会，およびその下にある各種作業部会や常駐代表 委員会の協議事項等の準備のため，毎週 $2 \sim 3$ 回会合を開催する。なお，同 委員会にはブリュッセルのイギリス常駐代表も参加する。ここで解決できな い問題は，内閣官房の次官代理（Deputy Secretary）が議長となり，次官補 レベルで構成される常設の欧州問題運営委員会（EQS）に上げられる。こ 
れら高級事務レベルで調整のつかない政治的問題は，関係省の閣僚レベルの 欧州閣僚委員会 (Ministerial Committee for Europe) に上程される。1972年11 月 5 日の内閣改造に際し，ヒース首相は，その議長としてランカスター公領

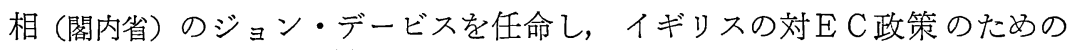
40) 省庁間調整にあたらせた。その後，内閣官房の欧州班は，総員約 30 名のスタ ッフ組織に拡大され，欧州室 (European Secretariat) と改称されている。 れによりイギリスは，対 $\mathrm{E} C$ 政策を展開するために，中央レベルに省間調整 のための計画スタッフ組織を設置した最初の加盟国となった。

以上のような加盟に伴う官僚機構の制度的対応を基礎に， $\mathrm{E} \mathrm{C}$ 諸機関への イギリス人派遣は，E C 委員会による職員採用選考への協力といら形態で行 なわれた。1973年 3 月国需尚書のジェリコ (Jellicoe) 卿が E C 委員会を訪 れイイギリス人採用に関する公式討議を開始した。行政管理省は，E C 諸機 関へのイギリス人派遣人事に対処するため，特別班を次官代理の下に設置し， 内閣官房欧州班と共に E C 職員人事に協力することになった。

ホワイトホールでは内閣委員会がこの問題に強い関心を示した。同委員会 に执いては内閣官房欧州室の次官代理が議長となり，行政管理省， E C 関係 省庁の次官補クラスが出席し，初期には E C 委員会のイギリス委員官房の職 員もこれに加わった。年こてではイギリス常駐代表部から欠員や組織再編に関 する情報を傍受し，人事に和いて目標とすべき官職を選び，イギリス人候補 者を送り达む戦略が練られたのである。

1981年11月12日イギリス議会下院に和いて，サッチャ一首相は創設以来13 年の歴史がある行政管理省を廃止すると宣言した。これに伴い国家公務員の 給与，諸手当，退職金等の事務は再び大蔵省へ吸収され，人事管理は内閣官 房のなかに新たに設置された「人事管理庁」(Management and Personnel Office) に委ねられた。したがって，対 $\mathrm{E}$ C 人事政策も同庁の上級職員欧州課で所掌 することになった。これによって E C 委員会総局の上層官職へのイギリス人 派遣問題は，内閣官房の直接の監督下に置かれることになったと考兄られる。 
E C の官僚制と加盟国の関係（福田）

以上のように各加盟国は，国内の政策調整や対 $\mathrm{E} C$ 人事政策をにらんだ官 僚機構の制度的対応をしてきたのであった。では，人事政策に限ってみれば その効果はいかなるものであったのだろらか。この問題を考觉る手掛かりと して，E C 職員の現実の国籍別在職状況の推移を概観して和きたい。

\section{$2 \mathrm{E} \mathrm{C}$ 委員会におけるA 類職員の国籍別在職状況}

$\mathrm{E} \mathrm{C}$ 職員規程第27条前段は，「共同体諸国民のなかからできる限り広い地 理的基盤のもとで」職員の募集・選抜を行ならことを義務づけている。そこ で共同体設立時には，この観点から各加盟国政府が自国の官僚制から抜䍜し た職員候補者名簿を提出するという方法がとられだ。では，各加盟国の国籍 間での官職の配分は，いかなる基準で行なわれるのか。それは原則として各 国の予算分担比率に比例させることが加盟国間で非公式に合意され，実施さ れた。この事実は，1960年にEＥＣ委員会事務局職員の国別配分比率に関し て，欧州議会に䑙ける議員質問に対する E E C 委員会自身の回答によって明 らかになった。すなわち原六加盟国間では，西ドイッ，フランス，イタリア が各25\%，ベネルクス三国で残りの25\%を配分するといら大枠が紳士協定に より合意された。この比率は，三執行機関の併合までほぼ守られていた。

1967年 7 月 1 日, 単一の E C 委員会への併合に伴ら A 類職員の国籍別在職 者数は，1968年 1 月19日付のル・モンド紙に発表された。その国別配分比率 を計算すると，西ドイッ $25.8 \%$ ，フランス $21.4 \%$ ，イタリア $24.7 \%$ ，ベルギ $-13.3 \%$ ，オランダ $9.6 \%$ ，ルクセンブルグ3.3\%，その他 $1.7 \%$ であった。 さらに1973年の第1 次拡大に伴い, 四大国は各18.4\%, アイルランドとデン マークは各 $4 \%$ の配分比率を確保することが計画された。しかし現実には第 1 表のように，かなりの不均衡があらわれた。EC委員会職員の国別配分は， 74年末の時点で四大国についてみると，A（L A ～D 類合計では，フランス 14.9\%，西ドイッ $16.3 \%$ ，イタリア $16.7 \%$ とほぼ均衡がとれているのに対 し，イギリスは僅か $8.4 \%$ に過ぎなかった。とはい光これをA類に限定し 
第 1 表 $E$ C 委員会, $A$ 類 $\cdot A(L A) \sim D$ 類職員国籍別在職状況 （1980年度は 6 月30日，他は各年12月31日現在）

\begin{tabular}{|c|c|c|c|c|c|c|c|c|c|c|c|c|}
\hline & 職類 & ドイッ & $\begin{array}{l}\text { イギ } \\
\text { リ }\end{array}$ & $\begin{array}{l}\text { フラ } \\
\text { ンス }\end{array}$ & $\begin{array}{l}\text { イタ } \\
\text { リア }\end{array}$ & $\begin{array}{l}\text { ベル } \\
\text { ギー }\end{array}$ & $\begin{array}{l}\text { オラ } \\
\text { ソダ }\end{array}$ & $\begin{array}{l}\text { ルクセ } \\
\text { ソブル } \\
\text { グ }\end{array}$ & $\left|\begin{array}{ll}\text { デ } & \text { マ } \\
\text { マーク }\end{array}\right|$ & $\begin{array}{l}\text { アイル } \\
\text { ランド }\end{array}$ & $\begin{array}{l}\text { ギリ } \\
\text { シア }\end{array}$ & その他 \\
\hline 1972 & $\begin{array}{c}\text { A } \\
\text { Total }\end{array}$ & $\begin{array}{l}25.0 \\
20.0\end{array}$ & & $\begin{array}{l}23.0 \\
17.0\end{array}$ & $\begin{array}{l}21.0 \\
18.0\end{array}$ & \multicolumn{3}{|c|}{$\begin{array}{r}30.0 \\
41.0\end{array}$} & & & & $\begin{array}{l}1.0 \\
4.0\end{array}$ \\
\hline \multirow{2}{*}{1974} & A & 18.7 & 14.9 & 18.5 & 18.2 & 13.1 & 6.3 & 3.1 & 3.8 & 3.0 & & 0.5 \\
\hline & Total & 16.3 & 8.4 & 14.9 & 16.7 & 26.2 & 6.0 & 5.1 & 3.7 & 1.9 & & 0.8 \\
\hline \multirow{2}{*}{1979} & A & 19.0 & 14.5 & 20.2 & 17.4 & \multirow{2}{*}{\multicolumn{3}{|c|}{$\begin{array}{l}22.4 \\
38\end{array}$}} & 3.0 & 2.9 & & 0.53 \\
\hline & Total & 14.7 & 9.5 & 14.2 & 17.0 & & & & 3.8 & 1.9 & & 0.90 \\
\hline \multirow{2}{*}{1980} & A & 18.8 & 14.3 & 20.4 & 17.5 & 13.3 & 6.0 & 2.8 & 3.0 & 3.0 & & 0.5 \\
\hline & Total & 14.6 & 9.4 & 14.0 & 17.0 & 26.8 & 5.7 & 5.2 & 3.8 & 1.9 & & 1.1 \\
\hline \multirow{2}{*}{1982} & A & 19.9 & 12.1 & 18.2 & 19.6 & \multirow{2}{*}{\multicolumn{3}{|c|}{$\begin{array}{l}21.3 \\
33.3\end{array}$}} & 2.5 & 2.4 & 3.7 & 0.3 \\
\hline & Total & 14.9 & 7.9 & 12.8 & 22.5 & & & & 3.2 & 1.6 & 3.0 & 0.8 \\
\hline
\end{tabular}

（出所）上記の表は，

Strasser, D., The Finances of Europe, 1981, p.316, Les Finances de l'Europe, 1984, p. 513., Willis, V., Britons in Brussels., 1982, pp.100-103, 加ら作成した。 （筆者による\%計算を含む。）

てみれば，イギリスは14.9\%で他の三カ国よりはやや低い占有率であるが， それ浮ど大きな差とはいい難い。特にその地理的条件や加盟直後であり， $\mathrm{E}$ C残留か脱退かで国内的にも混乱していた時期であったことに鑑みればむし ろ当然の結果であるとる推測できる。ところが 5 年後の 1979 年， 7 年後の 1982年と比較してみても，イギリスは依然低い比率にあることがわかる。こ れは, 欧州議会のダムソー (Damseaux・自由党・ベルギー) 議員, ダン・ニュ ートン(Newton Dunn・欧州民主党・イギリス) 議員の書面による質問に対する E C 委員会側の回答によって明らかになった。では，EＣ職員の国別配分の 原則をめぐる問題を，E C 裁判所はどのように判断し，なた現実に官職を占 める率の低い加盟国はどの程度の不利を被るのだろらか。

1）例塈ば，イギリスでは「E Cの地域政策および地域開発基金は，大藏省，産業省，環境 
省, スコットランド省, ウェールズ省, 北アイルランド省の六省の責任となっているので ある。」田中俊郎「英国の欧州共同体加盟にともならホワイトホールの対応」『現代中国と 世界一その政治的展開』慶應通信，1982年，940頁。

2) Sasse, Christoph, et al., Decision Making in the European Community, Praeger, New York, 1977, p. 8.

3) Ibid.

4) Ibid.

5) Ibid., Daltrop, Anne, Politics and European Community, Longman, 1982, p.81. $>$ ン・ダルトロップ著・金丸輝男監訳『ヨーロッパ共同体の政治』有斐閣, 1984年，118頁。

6) Ibid., Padova, Antonio Papisca, "La Présidence des CE: Rapport national sur la France", Nuallain, Colm O ed., The Presidency of the European Council of Ministers, Croom Helm, 1985, p. 124.

7) Ibid.

8) Ibid., p. 125.

9） Daltrop, Anne, op. cit., p. 81.『ヨーロッパ共同体の政治』, 118頁。

10) Steiner, Zara ed., The Times Survey of Foreign Ministries of the World, Times Books, London, 1982, p. 223 . 行政管理庁行政管理局監修『主要国行政機構ハンドブッ ク』ジャパンタイムズ編, 1980年, 195頁。

11) Padova, Antonio Papisca, op. cit., p. 124.

12) Sasse, Christoph, et al., op. cit., p. 10.

13) Ibid.

14) Sasse, Christoph, et al., op. cit., pp.12-13., Daltrop, Anne, op. cit., p. 81. Regelsberger, Elfriede \& Wessels, Wolfgang, "The Presidency of the Council of Ministers of the European Communities: National Paper on the Federal Republic of Germany", Nuallain, Colm O ed., op. cit., pp.77-9.

15）以下，行政規則の内容についてはすべて, Siedentopf, Heinrich, op. cit., pp.108-9. に拠る。

16) Ibid., pp. 108-9.

17) Ibid., p. 109.

18) Ibid.

19) Ibid., pp. 109-10.

20) Padova, Antonio Papisca, "La Présidence des CE; Rapport national sur L'Italie", Nuallain, Colm O, ed., op. cit., pp.167-8., Daltrop, Anne, op. cit., p. 81.

21) Sasse, Christoph, et al., op. cit., p. 20.

22) Ibid. 
23) Ibid.

24) Padova, Antonio Papisca, op. cit., p. 169, Sasse, Christoph, et al., op. cit., p. 21.

25) Ibid.

26) Ibid., pp.21-2.

27) Steiner, Zara ed., op. cit., p. 325.

28) Ibid.

29) Daltrop, Anne, op. cit., p. 81.

30）イギリス議会下院は，356対244で政府が提案する条件の下でイギリスが共同体に加盟す ることを承認した。Daltrop, Anne, op. cit., p. 33.『ヨーロッパ共同体の政治』48頁。

31) 33） Sasse, Christoph, et al., op. cit., p. 33. 田中俊郎前掲論文, 927頁。

34) Richards, S. G., Introduction to British Government, 2nd ed., Macmillan, 1984, p. 108., Greenwood, John \& Wilson, David, Public Administration in Britain, George Allen \& Unwin, 1984, pp. 65-68., pp. 96-8.

行政管理研究センター編『諸外国に括ける行政の総合調整に関する調査研究報告書』行 政管理研究センター, 1980年, 9 頁。

35）田中俊郎前掲論文, 942頁。Edwards, Geoffrey, “The Presidency of the EC: The Case of the United Kingdom", Nuallain, Colm O ed., op. cit., p. 240.., Sasse, Christoph, et al., p. 32.,

36) Ibid., p.32., Edwards, Geoffrey, op. cit., p. 240.

37) Ibid.

38）Ibid., 田中俊郎前掲論文，942頁。

39) Sasse, Christoph, et al., p. 32.

40）Ibid., p. 37. 田中俊郎前掲論文，917頁。

41) Edwards, Geoffrey, op. cit., p. 241.

42) Sasse, Christoph, et al., p. 34.

43) Willis, Virginia, Britons in Brussels, Policy Studies Institute, 1982, p. 26.

44) Ibid.

45) Edwards, Geoffrey, op. cit., p. 240.

46）Willis, Virginia, op. cit., p.26. 田中俊郎前揭論文, 942頁。

47）The Diplomatic Service List 1985, London, HMSO, 1985, p.71. (次頁表参照)

48）小池治「イギリス行政管理省の歴史と評価をめぐって (下)—Richard A. Chapman, "The Rise and Fall of the CSD", Policy and Politics, Vol.11, No.1 (1983), pp.4161 を中心に」『季刊・行政管理研究』行政管理研究センター, 1983, No. 24, 90頁。

49）同上, 88頁。Plowden, William, Administrative Reform in Britain (1965-1982), Inter- 
E C 官僚制と加盟国の関係（福田）

\begin{tabular}{|c|c|c|c|c|c|c|c|c|}
\hline & 大 使 & 公 使 & 参事官 & $\begin{array}{c}1 \\
\text { 書記菅 }\end{array}$ & $\begin{array}{c}2 \\
\text { 書記等 }\end{array}$ & $\begin{array}{c}3 \\
\text { 書記等 }\end{array}$ & 他 & 合 計 \\
\hline 1984 & 1 & 2 & 8 & 20 & 6 & 2 & 1 & 40 \\
\hline
\end{tabular}

(出所) The Diplomatic Service List, 1985 London, HMSO, 1985p.71 より作成。

national Institute of Administrative Sciences, 1982, pp. 11-12.

50) ウェルナー・フェルト前揭論文， 2 頁。

51）E E C 条約第 200 条旧規定。

52) Willis, Virginia, op. cit., p.10, Strasser, Daniel, op. cit., 1981, p. 316.

53) Coombes, D., op. cit., p.128., Michelmann, H.J., op. cit., 1978, p. 479.

54) Le Monde, 19, 1, 1968, p. 17.

55) Willis, Virginia, op. cit., p. 10.

56） Ibid., p. 82., 前揭拙稿, 105頁参照。

\section{III 多国籍人事と加盟国の関係をめぐる問題点}

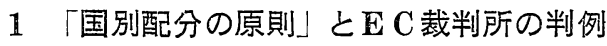

$\mathrm{E} \mathrm{C}$ 職員規程第27条は，できる限り広い地理的基盤において職員を採用し， また「特定の加盟国の国民のためにいかなる官職も留保してはならない」と も定めている。この条項は，いうまでもなく「国別配分」の原則をうたった ものである。ところが，この原則を実際に適用しょらとすると，多くの複雑 な問題が生じる。これらの問題を便宜的に整理するとすれば, 次の二つに要 約できよう。一つは，国別配分原則の適用範囲についての問題，他の一つは 国別配分原則と組織効率性確保の原則をいかに調和させるか，つまり候補者 の国籍と能力が対立する場合，そのいずれの基準を優先させるか，といら問 題である。すず国別配分原則の適用範囲をめぐる問題から考兄てみたい。こ の問題は，さらに次の三つの側面から分析することができる。(1)国別配分原 則は，第27条の文言通り採用に関してだけに限定して適用されるのか否か。

(2) E C 職員全体としてこの原則が確保されるだけでよいのか，各機関毎に適 用されるべきなのか，あるいは一層厳密に一機関内に沶いても各行政単位毎 
に適用される必要があるのか否か。(3)この原則が特に問題となるのは，いか なる職類や等級においてなのか，といら問題である。

第 1 の問題についての現実の答は，ラサール事件 (Case 15/63) が昇任をめ ぐる問題で争われたことからも明白である。すなわち第27条の募集・採用に 関する国別配分原則は，その意図するところを考慮して，採用のみならず昇 任や配置換などあらゆる段階での人事決定に㽎酌される。つまりラサール事 件では，「この原則は，職員の採用のみならず職務を退くまで彼のキャリア 3) 全体を通じて適用される」ことが明らかにされた。

次に，いかなる行政単位レベルでこの原則が適用されるべきか，といら第 2 の問題は, ラインナルツ事件 (Case 17/68) が次のような回答を与えている。 すなわち，「できる限り広い地理的基盤に基づいて職員の採用を確保すると いら義務の履行は，一総局内の僅かな数の官職に限定されてはならない」と。 国別配分原則は，一総局レベルではなく，E C 委員会のような一機関レベル において考慮すればよいと $\mathrm{E}$ C裁判所は判断したのである。

第 3 に，国別配分原則が特に問題となる職類，等級はどこかといら問題は， この原則に関係した過去の判例を見れば明らかになる。すなわちラサール事 件はA 3 級への昇任，七リ才事件 (Case 62/65) はA 6-7 級への採用，ライ ンナルッ事件 (Case 17/68) はA 2 級への採用，キュスター事件 (Case 22/75) は，A 3 級への採用をあぐる事件であった。すべてA類職員の問題であり， 特に政治的任命官職である上層等級に集中していることがわかる。

E A E C 委員会のA 6-7 級欠員官職への採用選考に関する1965年のセリ オ事件では，実際に採用されたベルギー人よりも上位の成績をとり，乙かも 法学博士の学位を持つばかりか欧州議会事務局臨時職員としての実務経験が あるにもかかわらず採用には至らなかったことについて，イタリア人である セリオ氏が訴えを起こした。職員規程第 27 条は，第 1 に最高水準の能力を有 する候補者の選任を，第2 にはできる限り広い地理的基盤からの採用といら 二つの義務を定めて和り，法理論上，能力の基準は地理的配分の基準に優先 
するはずだ，と彼は主張した。しかし本件について E C 裁判所は，EＡＥＣ 委員会によるベルギー人の任命は正しいと判決した。といらのは，EＡＥＣ 委員会の当該行政部局 (人事局) の六つの官職のらち三つまでが 既にイタリ ア人によって渪たされていたからである。

これは二つめに挙げた能力の基準と国籍の基準をいかに調和させ，また 両者が対立する場合には，そのいずれの基準を候補者の選任に揖いて優先す るのか, といら問題とかかわっている。ラサール事件では, 候補者に要求し た「完壁なイタリア語の知識」といら要件は職務上必要な能力ではなく，そ の真の意図が職員の国別配分を考慮してイタリア人の候補者を制限すること 12) 13) にあったとして問題になった。ラサール氏はフランス人であるが，このよう な欠員公示は「いかなる官職も特定の加盟国の国民のために留保してはなら ない」といら第27条第 3 項の規定に反するとして公示の取消を求める訴劣

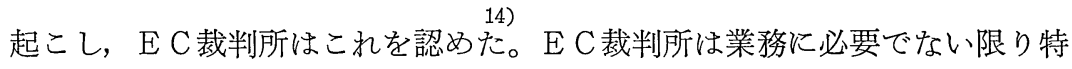
定の国籍を有していることは応募条件とはならず，特定の言語に精通してい るよう求めることで特定国人の排除を偽装すべきではない，と判断したので ある。つまり本件では，「これらの条項は，機関の利益を第 1 に意図してい る。その目的は第 7 条 [配置換の規定]において表明されるよらに『国籍を 考慮することなく, 職務の利益を専ら考慮する』ことを義務つけている」と 判示したのであった。

またラインナルツ事件では, 国別配分原則とキャリア展開との間に対立が 生じる場合，国籍均衡よりもキャリア展開，すなわら昇任の方に優先順位を 与光るべきである，といら見解を E C 裁判所は判示した。しかし同事件の判 決に执いて示された，国別配分原則は一総局レベルではなく，委員会事務局 レベルで考慮すれば足りるとする判断は，適当とい光るのであろらか。この 問題を加盟国相互の利害対立と人事決定との関連で, 現実の問題に即して考 它てみたい。

\section{2 加盟国の利害対立と人事決定}


各加盟国と E C 委員会を結びつける重要な役割を担うのは，前述の委員官 房である。E C 委員会に执いてこの組織は，各加盟国の国益と E C の超国家 的利益の調整, さらに E C 委員会職員の私的利害にまで関与している。 E C 委員会に护るA 類上層官僚の人事決定に対する委員官房の影響力は次のよ らにして生じる。

E C 委員会に抢いて委員官房は，多国籍人事が行なわれていない唯一の組 織である。そのため各加盟国の「飛び領土」(enclaves) とも呼ばれ，当該委 員から依頼された情報を収集するのがその主要任務となっている。A は，委員官房に情報を提供する代償として自らの昇任に有利な処遇をするよ う当該官房に要望する。ここに政治的交換が成立するのである。

しかし時には，これが A 類職員の士気の低下や政治的秘密の漏洩を示唆す ることにもなりかねない。E C の政策決定過程，特に E C 委員会内部の意思 決定過程を振り返ってみれば，その点は一層明白になる。簡単にいえば，(1) E C 委員会が一つの事案についての方向づけを行ない，主務委員之担当総局 を確定し，これらが中心となって各加盟国政府，行政官庁，専門家等からの 意見聴取，情報収集を行ない，各種職能団体や作業部会の資料・報告等に基 ついて研究を重ねて第 1 次企画案を作成する準備段階，(2)この第 1 次企画案 を基に，担当総局が，各加盟国の法制度・行政実務を調查検討する作業部会， 各種職能団体（UN I C E，COP A, 労連など）の代表との会合をもち，さら に担当委員とその委員官房, 法務部々の他の総局と意見調整を図り, 企画案 を確定する協議段階，(3)この企画案の内容について閣僚理事会（常駐代表委 員会)，経済・社会評議会，欧州議会の関係委員会と情報の交換をした後， $\mathrm{E} C$ 委員会にはかり，多数決で承認されてはじめて公式の $\mathrm{E} C$ 委員会提案と 23) なる。

それゆ光個々の総局が策定する政策や提案の内容を事前にできるだけ早く 傍受する必要から, 各委員官房は E C 委員会 $\mathrm{A}$ 類職員の間に情報網を張り巡 らせている。一総局が最終的な政策の原案, 企画案としてEC委員会へ上程 
E C 官僚制と加盟国の関係（福田）

する以前に，これらを検討し，当該国に有利な方向へできる限り変更させる 準備をするのが各委員官房の任務である。委員官房は自国の主張を正当化で きるだけの資料や情報を収集しまた自国にとって重要な総局の主要官職に 欠員ができないか常に目を光らせ，当該委員や常駐代表部に教示し，また本 国政府と連絡をとる。というのは，E C 委員会に和いて最終的な決定が下さ れれば公式の委員会提案として発議されてしまい，また人事決定は最終決定 となるからである。各委員官房長は，EＣ委員会の事務局長を議長として毎 週会合を開く。この委員官房長会議では, 他の委員官房との意見調整や E C 委員会での協議事項についての準備を行なら。また，この会合で合意された 事項 (A項目) は，次のE C 委員会に打いて審議せずに承認される。これは 常駐代表委員会第 1 部が，技術的性格の強い域内市場事項を議題 $\mathrm{A}$ として理 事会に上程し, 理事会では審議せずに採択する議題 $\mathrm{A}$ 手続と同様である。こ のことからも，委員官房は E C 委員会に拈いて加盟国の常駐代表部としての 役割を演じていることがわかる。さらに閣僚理事会の常駐代表委員会に相当 する委員官房長会議では, 問題の本質的な争点についても議論し，その要旨 は各委員に伝えられる。EC委員会に新ける政治的妥協の基礎は, 事実上こ の段階で形成されるものと考壳られる。

ところが，委員官房がこのような重要な役割を演じるだけに， E C 職員の 人事決定にもしばしば介入する。例兄ば，ある委員官房は，自国の国益にと って重要な政策領域を管轄する総局に目を付ける。そしてその総局のA類官 職へ自国出身の有能な人材を送り込み, 自国の政策を $\mathrm{E} C$ の政策形成に反映 させたり，共通政策の実施過程で行政裁量の余地がある領域において当該官 僚が自国の国益を配慮した行動をとることを期待する。

では，それは現実にどの程度可能であるのだろらか。自国にとってょり多 くの利益を引き出せる政策領域を管轄する総局の主要官職を，特定国出身官 僚で牛耳ることがいかに特定国の国益に貢献するか，といら問題は，1981年 6 月 3 日会期のイギリス議会上院の審議に预いて明らかにされた。 
問題の争点は，口メ協定の下での E E C 開発援助政策から得られるイギリ スの利益についてであった。イギリス議会上院議事録によれば，キッシン (Kissin) 卿が「共同体原加盟国は，その外交的，官僚的圧力を行使すること によって他の〔新規】加盟国に損害を与えている」と述べ，その実例として

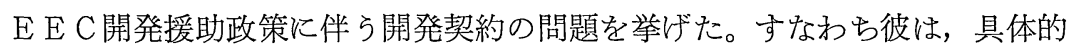
にフランスが全開発契約のらち $33 \%$ 獲得したのに比べ，イギリスは $11.2 \%$ しか獲得できなかったという事実を指摘した。さらに別の作業契約の場合に は,フランスは43\%のシェアーを獲得できたがイギリスは僅か $7 \%$ に過ぎな 32)

かったと強調した。その原因として彼は，これらの開発に関する契約手続の 監督や開発の技術的・財政的側面の監視, プロジェクトの準備や実施後の評 価がすべて開発総局 (DG-VIII) の裁量に委ねられている点を挙げた。イギリ スが不利になった理由としてキッシン議員は，「特に発展途上諸国の問題に 関係する総局にイギリス人職員が適切に代表されていない」からであると指 摘した。それゆえイギリス政府は，ブリュッセルに拈けるイギリスのパワー の通路となる E C 委員会高級官僚の人事にもっと積極的なアプローチをとり， 「すっと均衡のとれた代表」を達成すべきである，と強く要請した。またフ ランス人関係者にこのことについて不泱を表明したところ, 逆にイギリス政 府は「もっとイギリス人職員を重要な総局へ『押し込む』べきだ」と促がさ れたという事実も披露された。開発総局職員の等級別国籍配分状況は，公式 には明らかにされていない。が，実際，漁業，地域政策総局では1980年当時 A 4 級以下にしかイギリス出身者がいない，という指摘もある。

これらの事実や指摘からもわかるように，A類職員に関する人事決定は各 加盟国の国益にも影響を及ぼすため，各国の重大な関心事となっている。特 にA 類上層官職に進む程， E C の政策決定に果す役割が大きいため，その人 事決定には委員官房の影響力が強まる。特に総局長 (A 1) の任命について は，各委員官房間で非常に加熱したバーゲニングが行なわれるといわれる。 これが総局長と国籍の異なる委員との間の関係を悪化させる原因にもなって 
いる。それゆ觉『シュピィーレンブルグ報告』では，各委員官房の職員数を 厳格に制限し，官房長会議に総局長も出席できるように改革することによっ て総局長の権限を強化すべきであると勧告している。また 同報告書第 3 部 (職員人事政策)の改革勧告の実施を検討するために続いて『オルトリー報告』 が作成された。同報告に和いて，E C 委員会に拈ける委員官房の役割の重要 性を評価しつつも，割拠主義的傾向のある総局相互間の適切な調整を図る観 点から，A類上層職員の人事に対する委員官房の過大な影響力行使を抑制す 40) べきである，と勧告している。こうしたE Cの行政改革は，まだ緒についた ばかりである。これらの報告の答申で示された改革案の断行が今後の重要な 課題となろう。

1） E C 職員規程の文言上は，「地理的基盤」（geographical bace）となっているが， E C

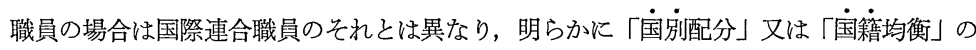
原則である。国連の地理的配分々ついては, 辻清明「国際行政学への一試論」『社会科学 ジャーナル』第15号, 国際基督教大学, 1977年, 21- 5 頁参照。

2) Claude Lassalle 事件 (Case 15/63, E.C.R., 4.3.1964), p. 31.

3) Ibid., p. 34.

4) Andreas Reinarz 事件 (Case 17/68, 6.5.1969).

5) Ibid., p.61, 72. 牞よび Rogalla, Dleter, op. cit., p. 90.

6) Manlio Serio 事件 (Case 62/65, 15.12.1966), p. 562 .

7) Case $17 / 68$, pp. $62-3$.

8) Berthold Küster 事件 (Case 22/75, 29.10.1975), p. 1269.

9) Case $62 / 65$, p. 562 .

10) Ibid., p. 565.

11) Ibid., p. 562.

12） H. G.シュヘルメルス著, 金井, 辰巳，瀬川，藤川訳『国際機構法(上)』啓文社，1981 年, $234-5$ 頁。

13) Case $15 / 63$, p. 32 .

14) Case $17 / 68$, p. 40.

15) Ibid., p. 37.

16）「任命権者は，専ら職務の利益のためにから国籍を考慮することなく，職員をとの等級 に対応するカテゴリーホたはカードルの職洒置しあるいは配置換古する」（E C 職員規 程第 7 条第 1 項) 谷本治三郎訳「欧州共同体職員規程 $(-)$ 『法学論集』大阪経済法科大学, 
1979年, 131頁。

17) Case $15 / 63$, p. 37.

18) Case $17 / 68$, p. 73. , Rogalla, Dleter, op. cit., p. 90.

19) Michelmann, H.J., 1978, op. cit., p. 482. Bull, EC 9-1979, p. 22, Spierenburg Report, Brussels, 1979, p. 19.

20）前掲拙稿, 109-10頁。

21〜23） J ．シジャンスキ著, 中原喜一郎訳『ヨーロッパの圧力団体』ミネルヴァ, 146一 7 頁。

24）前掲拙稿, 110 一 11 頁。

25）同上。

26) Spierenburg Report, op. cit., pp. 20-21. Sasse, C., et al., op. cit., pp.163-4.

27) Ibid.

28）小室程夫「E E C に护ける理事会と委員会の権限関係」『日本 E C 学会年報』第 1 号, 有斐閣, 1981年, 20-1頁。

29) House of Lords, Select Committee Report on Development Aid Policy in the EEC., ECC 21st Report, 13.6.1981, H. L. 146. pp.1226-1305.

30) Ibid., p. 1264.

31) 32) Ibid.

33) Ibid., p. 1265.

34) Ibid.

35) Ibid.

36) Willis, Virginia, op. cit., p. 8.

37）Ibid., pp.18-9.イギリスは，基金配分に関係する総局において実質的に低い占有率と なっている。例えば，D G-X (情報) は $23 \%$ A 類職員の占有率であるのに対し， D GVI (農業) は $10.5 \%, D G-X I$ (地域政策) は $9 \%, D G-V$ (社会問題) は $12.3 \%$ 占有 率となっている。

38）前掲拙稿, 111頁。

39) EC Commission, "Report of the Group of Members of the Commission set up to study the implementation of Part Three of the Spierenburg Report”, Brussels, 1980. 40) Ibid., pp. 2-6.

\section{おわりに}

以上，E C官僚制と加盟国の関係について，人事政策をめぐる問題を中心 
E C 官僚制と加盟国の関係（福田）

に概観した。その結果，次のような特徵が明らかになった。第】に， E C 委 員会官僚制は，多国籍人事を原則とする超国家的性格をるつ国際官僚制を確 立した後も，加盟国とは全く無関係な存在としてではなく，むしろ人事政策 をはじめとして各種の政策決定や運営過程に加盟国政府・官僚制を巻き込み， 緊密な連熬協力の仕組を作り上げた。

第2 に，E C 委員会の超国家性，政治的中立性，そして独立性の確保とい ら観点から，その官僚制に和ける人事は，国籍均衡の原則を念頭に括きつつ も，最終的には組織効率性を確保するために国籍よりも能力を基準として決 定が行なわれる傾向があることを指摘できる。ただ， E C 職員の国別配分原 則が厳格に配慮されるのは，競合する候補者の能力が同等，もしくは当該部 局に括ける特定国の占有率が異常に高い場合に限られるといってよい。

第 3 に，各加盟国政府とその官僚制は，EＣの政策を受け入れたり，自国

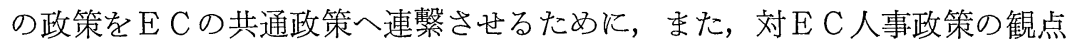
から，国内省庁の総合的調整が必要となり，これが可能となるような制度的 対応をした点に注目しなければならない。なぜなら，それは国家の枠内に 括将る中央政府・地方政府間の，又心地方政府相互間の既存 の 政府間関係 (intergovernmental relations) に，国家の枠を越えた $\mathrm{E} C$ といら新たな超国家 的レベルの「政府」が加わったことを意味するからである。一方では各加盟 国の中央政府官庁，地方政府の諸機関がいわば E C の「機関委任事務」を行

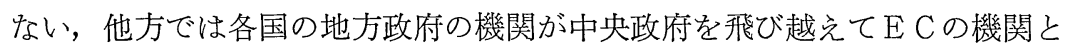
直接政府間関係をもつようになってきている。これは国家の枠を前提とした 伝統的な行政理論や地方自治理論に対する現実の根本的な挑戦であり, 問題 提起でもあるといえる。

いずれにせよ，E C の存在自体が各加盟国の行政制度や行政文化の相違を のり越光させる契機となり, 共同体行政と加盟国行政の有機的な連繋を強化 してきた。また，今後もさらに発展する方向にある。このよらにして E C 的 次元での公共政策の決定様式を徐々に整えることにより，E C はさらなる政 
治統合推進に向けて確固たる基礎を築きつつあるとい方よう。

本稿は，1985年11月10日第 6 回日本 $\mathrm{E} \mathrm{C}$ 学会（於・名古屋大学）での報告に加筆 修正したものである。 